\title{
A Maturation Model for Project-Based Organisations - WITH UNCERTAINTY MANAGEMENT AS AN EVER-PRESENT Multi-PROJECT MANAGEMENT FoCUS
}

\author{
Anna Jerbrant \\ School of Industrial Engineering and Management, KTH Royal Institute of Technology
}

Accepted: December 2013

The classical view of multi-project management does not capture its dynamic nature. Current theory falls
short in its ability to explain how the management of project-based companies evolves because of their
need to be agile and adaptable in a changing environment. The purpose of this paper is therefore to present
a descriptive model that elucidates the maturation processes in a project-based organisation as well as to
provide an enhanced understanding of multi-project management in practice. The maturation model
illustrates the way the management of project-based organisations evolves between structuring
administration and managing uncertainties, and emphasises the importance of active individual actions and
situated management actions that have to be undertaken in order to coordinate, synchronise and
communicate the required knowledge and skills. The outcomes primarily reveal that, although standardised
project models are used and considerable resources are spent on effective project portfolio management,
the way information and communication are dealt with is vitally important in the management of project-
based organisations. This is particularly true of informal and non-codified communication.

Key words: project-based organizations, project portfolio management, multi-project management, multiproject settings, project-management office, project maturity

JEL: L200

\section{1}

\section{Introduction}

The organisational design of project-based organisations (PBOs), where a large number of operations are organised as simultaneous or successive projects, is often complex and challenging to manage (Hobday, 2000; Engwall \& Jerbrant, 2003; Elonen \& Artto, 2003; Sydow, Lindkvist \& DeFillipi, 2004; Söderlund \& Tell, 2009; Arvidsson, 2009; Jerbrant, 2013; Jerbrant \& Gustavsson, 2013). And once the complexity involved in managing, controlling and organising a project-based organisation is revealed, there is increased focus on time and activity planning in order to facilitate the coordination of scarce resources within tight time limits. On the one hand, the main focus of the dominant strand of multi-project management theory aims is improve efficiency and rationality in the structuring of the project portfolio's performance, through the use of practical models and tools for effective resource allocation and project prioritisation (De Maio, Verganti \& Corso, 1994; Van der Merwe, 1997; Cooper, Edgett \& Kleinschmidt, 2002; Danilovic \& Sandkull, 2005; Moore, 2010). Nevertheless, the interdependencies that arise between different projects, as well as between projects and their environment, remain significantly difficult (Cooper et al., 2002; Engwall \& Jerbrant, 2003; Engwall, 2003; Blichfeldt \& Eskerod, 2008).

Project portfolio management (PPM) tools and techniques, on the other hand, are often based on the ability to handle preconditions that may vary-for several projects-from one day to the next, making prioritising and planning difficult. In addition, most project-intensive organisational settings are subject to considerable time pressures and constantly changing project organisation practices (Eskerod, 1996; Ward \& Chapman, 2003). Consequently, the notion of flexibility is very important in the context of PPM (Petit \& Hobbs, 2010), with the result that collaborative and communicative managerial activities have become increasingly important 
(Dainty, Moore \& Murray, 2006; Winch, 2010). This in turn makes the concept of uncertainty management with regard to both project management and project portfolio management essential (Petit \& Hobbs, 2010; Petit, 2012).

\subsection{Aim and contribution}

This paper is a response to the demand for research aimed at understanding organisational project management structures and the dynamics in project-based organisations (Aubry, Hobbs \& Thuillier, 2007, 2008; Petit, 2012). The research is focused on changes in and the maturation of the management and organisation of PBOs, and the purpose of this paper is to present a descriptive model that elucidates the maturation processes in a project-based organisation as well as to provide an enhanced understanding of multi-project management in practice. Therefore, the overall aim of the paper is to enhance understanding of how the management of project-based companies should evolve, in view of their need to be agile and adaptable in a changing environment, to achieve a balance between structuring administration and managing potential uncertainty. The outcomes primarily reveal that, although standardised project models are used and considerable resources are spent on effective project portfolio management, the way information and communication are dealt with in the organisation is vital for the effective management of PBOs. This is particularly true of informal and noncodified communication. The principal findings of this study are presented in this paper, namely both a maturation model of PBOs that illustrates how multi-project management evolves between structuring administration and managing potential uncertainty, and an identified emphasis on the importance of positive individual actions and situated management actions that have to be undertaken in order to coordinate, synchronise and communicate the required knowledge and skills.

2

\section{Research design}

This research belongs to a discipline that embraces social construction (Berger \& Luckman, 1998) and the importance of studying the meanings that different individuals assign to their reality (Lindfors, 1993). This research design is therefore differentiated from traditional project research and the positivist approach that characterises it (Blomquist, Hällgren, Nilsson \& Söderholm, 2009). Inspired by hermeneutics (Lindfors, 1993), which emphasise interpretation, I have concentrated in my research on looking for context-bound meaning or significance based on empirical, in-depth studies (Lindfors, 1993). The research presented here is based on an inductive and qualitative case-study approach that is exploratory and is grounded in an indepth analysis of two individual cases (Jerbrant, $2009,2013)$. The purpose of the empirical fieldwork was to generate concepts, theoretical models and empirical issues that would guide further research on multi-project settings as an empirical phenomenon. This approach increased the likelihood of uncovering the unknown. The approach to the empirical fieldwork was also inspired by grounded theory (Glaser \& Strauss, 1967) in the sense that a central activity was the generation of a description that captured vital aspects of the phenomenon under study.

\subsection{Empirical data collection}

Two qualitative case studies carried out at two different project-based industrial companies form the empirical basis of this study. An ethnographically inspired approach was chosen in order to form an in-depth understanding of the practices. As in most ethnographic research, several sources of data were used (observations, interviews, studies of written material, project documentation, technical documents, minutes, company instructions and memos). The total duration of the case studies was one-and-a-half years, and during this time, participant observation was performed three to four days per week in a sequential order at both organisations. In line with the perspective of the study, the empirical data collection began with the interviewing of division managers. This "tour" gave the researcher a broad picture and helped to create contextual awareness. Subsequently, interviews were held with departmental managers; project managers and several subproject managers at the functional departments were also interviewed. All in all, approximately 55 semi-structured in-depth interviews were held and transcribed. The longest interview took about four hours, the shortest approximately 30 minutes. On average, 
the interviews lasted one-and-a-half hours.

The first case study was conducted at a contract division that was one of four divisions in a medium-sized engineering company. At the time of the study, the company had approximately 500 employees who engineered, produced and installed signalling and safety systems for railways. The second case study was conducted at an R\&D division that was one of six divisions within a medium-sized, private telecom operator. At the time of the study, the company had approximately 500 employees, and was the third biggest telecom operator in the country in terms of capacity. It owned and operated networks for telecommunication, data communication and the internet, and provided services for both private and professional customers.

The second study was initiated in order to increase in-depth understanding, as well as to test the validity of the findings from the first case study. This organisation was chosen as a contrast with the organisation in the first case study. Consequently, the study had a similar research design, and was executed over a shorter period of time.

Table 1

Empirical data collection in summary

\begin{tabular}{|l|l|l|}
\hline \multicolumn{1}{|l|}{} & \multicolumn{1}{|c|}{ First case study } & \multicolumn{1}{c|}{ Second case study } \\
\hline Focus & $\begin{array}{l}\text { Focus on the management and execution of } \\
\text { the multi-project business and the PMO } \\
\text { manager. }\end{array}$ & $\begin{array}{l}\text { Focus on the management and execution of } \\
\text { the multi-project business and the PMO } \\
\text { manager. }\end{array}$ \\
\hline Data collection method & $\begin{array}{l}\text { Longitudinal case study inspired by both } \\
\text { ethnographic and grounded theory. }\end{array}$ & $\begin{array}{l}\text { Longitudinal case study inspired by both } \\
\text { ethnographic and grounded theory. }\end{array}$ \\
\hline a) Interviews & $\begin{array}{l}35 \text { semi-structured deep interviews } \\
\text { The longest interview was about 4 hours long, } \\
\text { the shortest approx. 30 minutes. On average, } \\
\text { they were approx. 11/2 hours long. }\end{array}$ & $\begin{array}{l}\text { 20 semi-structured in-depth interviews } \\
\text { The longest interview was about 4 hours long, } \\
\text { the shortest approx. 30 minutes. On average, } \\
\text { they were approx. 11/2 hours long. }\end{array}$ \\
\hline b) Observation & $\begin{array}{l}\text { Three days a week for one year at the main } \\
\text { office. }\end{array}$ & $\begin{array}{l}\text { Three days a week for three months at the } \\
\text { main office. }\end{array}$ \\
\hline c) Meetings & $\begin{array}{l}\text { Approx. 10-15 steering-group meetings, 2 } \\
\text { concluding workshops/seminars. }\end{array}$ & $\begin{array}{l}\text { Approx. 5-6 steering-group meetings, 2 } \\
\text { concluding workshops/seminars. }\end{array}$ \\
\hline d) Documentation & $\begin{array}{l}\text { Project-related documentation, project plans, } \\
\text { project reports, progress reports, steering- } \\
\text { group protocols, work process descriptions, } \\
\text { and documents describing the technology and } \\
\text { products, and company history. }\end{array}$ & $\begin{array}{l}\text { Project-related documentation, project plans, } \\
\text { project reports, progress reports, steering- } \\
\text { group protocols, work process descriptions, } \\
\text { and documents describing the technology and } \\
\text { products, and company history. }\end{array}$ \\
\hline e) Other & $\begin{array}{l}\text { Approx. 100 hrs of informal meetings, lunches, } \\
\text { coffee breaks, etc. }\end{array}$ & $\begin{array}{l}\text { Approx. 100 hrs of informal meetings, lunches, } \\
\text { coffee breaks, etc. }\end{array}$ \\
\hline
\end{tabular}

\subsection{Data analysis}

Based on the chosen research design, interpretation is the tool which has enabled this research to move from empirical descriptions to theoretical contributions. Therefore, both similarities and differences were emphasised without the need to generalise, since the description of the phenomenon under study is inter-subjective and constructed on social interactions, based upon the researcher's interpretations, rather than a representation of reality. At the same time, this research was inspired by a project-as-practice perspective (Blomquist, Hällgren, Nilsson \& Söderholm, 2009), which makes a distinct contribution to the understanding of project-based organisations owing to its focus on organising on the basis of situated actions. Further, the benefits are increased if the practice perspective is explicitly anchored in a process ontology (Sergi, 2012) since this enables the recognition of change over time. This approach is highly suitable since these results clearly focus on change, movement, and transition ${ }^{1}$ over time in both companies' project-based organisations.

Accordingly, it was possible in the course of empirical data collection to identify and document the structural processes mainly through the written documentation and some of the interviews; uncertainty management was documented through observations and the descriptions given in certain interviews. Therefore, when analysing the empirical material, the procedural focus made it easier to recognise 
how the situated actions unfolded and changed over time.

\section{3}

\section{Literature review}

This section will provide an overview of the research literature on the subject of the management of project-based organisations. The aim is to focus on the key characteristics of multi-project management literature and then to describe specific contributions to the management of project-based organisations attempting to deal with rising internal and external environmental uncertainties.

\subsection{Key characteristics of multi-project management theory}

Most multi-project management literature focuses on resource allocation, control and prioritisation between projects (Gunnarson, Linde \& Loid, 2000; McDonough \& Spital, 2003; Crawford, Pollack \& England, 2006; Dawidson, 2006; Jerbrant, 2009). The greater part of project portfolio management research follows a rational perspective and develops tools, techniques and methods that focus on structure and control (Cooper et al., 2002; McDonough \& Spital, 2003; De Reyck, Grushka-Cockayne, Lockett, Caldemi, Moura \& Sloper, 2005; Dawidson, 2006; Turner, 2009; Moore, 2010; Teller, Under, Kock \& Gemünden, 2012). The managers of project portfolios are often swamped by issues relating to the prioritisation of projects and the distribution of personnel from low-priority and smooth-running projects with a surplus of resources, to high-priority projects and projects in crisis (Blichfeldt \& Eskerod, 2008). However, one major problem in a project-based business is that most of the time there are no surplus resources available. Hence, most management and control routines in multi-project management consist primarily of tools and techniques to manage resource allocation, prioritisation and project selection in the most effective way possible (Hendriks, Voeten \& Kroep, 1999; Cooper et al., 2002; Pennypacker \& Dye, 2002; Turner, 2009; Moore, 2010). The growing popularity of project portfolio management in theory and practice, together with the rational tools for structuring work and directing responsibility, has prompted an acceleration of the formalisation movement (Thiry \& Deguire, 2007). As a result, most of the literature focuses on the following aspects: process structure implementation to support project selection and portfolio design; scheduling, resource allocation algorithms and prioritisation, and the development of funnels and project management models.

One of the most usual ways to initiate and emphasise structure and planning in a projectbased organisation is to establish a project management office (PMO). The primary aim of creating a PMO is usually to increase the number of successful projects and to standardise the performance of individual projects as far as possible. An important task for project management offices is consequently improvement of project portfolio management, for instance by initiating or enhancing project proposal submission, project selection, resource allocation, prioritisation and risk management (Moore, 2010). One of the aspects on which the most emphasis is placed when it comes to optimising an existing project portfolio is the creation of transparency through clear goals, roles and processes (Jonas, Kock \& Gemünden, 2010). This is often accomplished with an initial focus on managing single projects because without project management formalisation, the formalisation of project portfolio management is elusive (Teller et al., 2012). Thiry and Deguire (2007) state that the growing popularity of programme/ portfolio management and the emergence of a project management office (PMO) as an organisational unit provide impetus for the creation of project-based organisational structures.

One main advantage that is often emphasised when introducing a project management office is that the organisation gains a control unit, which is able to respond to many different needs by handling various functions, such as: project definition and planning, cost/benefit analysis of projects, risk management, monitoring and control, access to experience and knowledge, support of project management processes and procedures, knowledge capture and dissemination, provision of specialist skills, and maintenance of project tools, standards and processes (Pellegrinelli \& Garagna, 2009). At the same time, PMOs are often perceived as the battleground between empowerment and control, between people and processes, and between different political groupings (Pellegrinelli \& 
Garagna, 2009), and organisational tensions are often cited as one of the main driving forces behind the introduction and transformation of the PMO. There is a substantial need for flexibility in project portfolio management because of the internal organisational tensions (Arvidsson, 2009). The organisational tensions described by Arvidsson (2009) are often created by problems in synergy between permanent (line) and temporary (project) functions, and they often take place in organisations where project work has recently been introduced and project strategic alignment, resource allocation, prioritisation and knowledge capturing have not become standardised.

During the last decade, views on how to manage project-based organisations have changed, from a sole focus on marketing the use of standardised management processes to a more strategic perspective on the entire project portfolio (Dvir, Raz \& Shenhar, 2002; Thiry \& Deguire, 2007; Meskendahl, 2010). For instance, Pellegrinelli, Partington, Hemingway, Mohdzain \& Shah (2007) argue that the "strategic management or strategic planning" disciplines perceive the introduction of programmes as a way to implement a strategy, bringing about business change, and as an alternative means of organising project-based activities. Meskendahl (2010) emphasises that the managerial focus of firms has shifted towards the management of project portfolios as a whole, and towards the effective link to overall business goals. Many organisations may have well-defined and well-scoped strategic processes (Moore, 2010), but it is also important to discuss the concept of strategic fit in regard to project portfolio management (Meskendahl, 2010). Strategy should be placed before project portfolio selection and, furthermore, the strategic goals should ideally be relatively limited. Finally, when discussing strategic alignment, projects and especially project portfolios are often emphasised as "powerful strategic weapons" and central building blocks for implementing the intended strategy.

\subsection{The need for uncertainty management and a dynamic approach}

Several researchers have recently begun to argue that instead of more scheduling, progress reports, or the spending of more time on review meetings, the whole system of managerial procedures for PBOs should be reconceptualised from the ground upwards. In contemporary research, appeals are made for a better understanding of project portfolio dynamics; the main areas under discussion include the need for a holistic approach in multi-project companies on the "edge of chaos" (Eskerod, 1996; Blichfeldt \& Eskerod, 2008; Geraldi, 2008; Jerbrant, 2009; Petit 2012). This means that the overly static conception that has dominated the literature is being contrasted with a more dynamic approach. Viewing a project-based organisation like a Chinese dragon is a good analogy: an untamed creature in a complex interaction with the given circumstances and the project (and portfolio) manager's ability to manage and improvise based on those facts (Eskerod, 1996). But how is it possible to manage and organise something that functions like a living dragon? What seems like the right thing to do at one moment may be completely wrong at the next because of the changing environment; it is therefore necessary to prepare the organisation to cope with the stress involved in managing unexpected events (Eskerod 1996; Geraldi, Lee-Kelley \& Kutsch, 2010; Ward \& Chapman, 2003). Although both Ward \& Chapman (2003) and Geraldi et al. (2010) focus on the management of single projects, their results are highly relevant for project portfolio management as well. Geraldi et al. (2010) argue that it is crucial to build organisations that are able to manage the unexpected and the resulting contextual complexity and cascading effects; unexpected events will always occur in at-risk systems. Therefore, Geraldi et al. (2010) emphasise that, on an organisational level, it is important to take time to confirm decisions, and on a group level, it is important for stakeholders to be involved and create room to negotiate (communicate) with each other regarding different solutions. Finally, on an individual level, it is important to have well-defined leadership, good teamwork, the necessary resources and expertise available at the right time, and the ability to handle stressful situations without panic when unexpected events occur. To summarise, Geraldi et al. (2010) reflect upon individual skills and competencies, which transform relations and communication on a project team level, and manifest through a 
responsive organisation that empowers individuals. While human behaviour issues play a major role in Geraldi's findings, Ward and Chapman (2003) are more focused on the need for uncertainty management. Uncertainty, according to them, is not only about "lack of certainty" but is also about the "ambiguity" associated with lack of clarity, lack of data, lack of detail, lack of structure, known and unknown sources of bias, and ignorance about how much effort it is worth spending to clarify the situation (Ward \& Chapman, 2003). Therefore, uncertainty management is not just about managing perceived threats or opportunities and their implications. The key concept is rather about understanding where and why uncertainty is important in a given project context, and where it is not (Ward \& Chapman 2003). Their conclusions focus on how project managers should emphasise uncertainty management rather than risk management, but in a multi-project context what they have to say is equally applicable to project portfolio management.

Petit (2012) and Petit and Hobbs (2010) present a conceptual framework that emphasises the operational processes needed when managing project portfolios in dynamic environments. These processes are labelled sensing, seizing, and reconfiguring. Sensing refers to the structures, tools and processes needed to sense, filter and interpret changes and uncertainties. Seizing refers to the structures, tools and procedures for identifying the fact that changes are required once uncertainty has been sensed. And reconfiguring is defined as the actions taken to ensure the alignment of projects and resources with the changes identified by the sensing mechanisms and decided upon in seizing (Petit, 2012). According to Petit (2012), this will enable project portfolio management practices to operate successfully. By acknowledging the frequent occurrence of unexpected events in project work, the organisation builds processes for adaptation to change in the corporate culture and strengthens the alignment of strategy and the external environment. Further, instead of featuring only routinebased, tacit and team-embodied adaptation capabilities, the conscious and deliberate efforts of top managers must be emphasised (Lindkvist, 2004).
Geraldi (2008) notes that project-based companies could increase their competitive advantage by adopting organisational structures that are "on the edge of chaos". For multiproject firms being on the edge of chaos implies having a sound balance between the complexity of project portfolios and the flexibility of their organisational units. According to Geraldi (2008), balancing on the edge of chaos enables companies to cope with a variety of changing requirements for a certain period of time, thereby enhancing their dynamic capabilities. This is a must for project-based companies since (according to many management and organisational models) successful organisations are those that manage to combine both organisational creativity and innovation with mechanical efficiency, "i.e. organisation[s] able to deal with the coexistence of chaos and order" (Geraldi, 2008). The term "on the edge of chaos" implies that different dimensions must coexist in the same organisation. There are two major advantages for a project-based organisation in existing "on the edge of chaos." First, the coexistence of order and chaos is said to enable companies to deal with heterogeneous demands such as differentiation and integration simultaneously. And second, this way of thinking supports organisations' change management and therefore makes dynamic stability possible (Geraldi, 2008).

But of course, regarding a specific firm's project portfolio, there is a maximum range of heterogeneity that is possible to integrate, and Geraldi (2008) states that multi-project businesses must be understood as dynamic systems, embedded in history and contexts where flexibility and complexity interface, are mutually dependent, and vary over time.

\section{4}

\section{Empirical findings}

The findings section first presents a table that summarises the most relevant information about the case-study companies (briefly shown on pages 3 and 4). Next the findings are presented from an internal perspective with a procedural structure to support the discussion that follows. 


\begin{tabular}{|c|c|c|}
\hline & \multirow{3}{*}{$\begin{array}{c}\text { Table } 2 \\
\text { Summary of empirical setting }\end{array}$} & \\
\hline & & \\
\hline & & \\
\hline & Contract Division & R\&D Division \\
\hline Responsibility & $\begin{array}{l}\text { The production of the company, i.e., all the } \\
\text { engineering activities involved in the } \\
\text { execution of major contracts (projects) for } \\
\text { different clients in all parts of the world ( } 80 \\
\% \text { of the company's turnover). }\end{array}$ & $\begin{array}{l}\text { To safeguard the company's survival in } \\
\text { those markets where it is already present, } \\
\text { and to enable the company to compete in } \\
\text { new markets. }\end{array}$ \\
\hline Size & Approx. 200 employees. & Approx. 50 employees. \\
\hline Departmental structure & $\begin{array}{l}\text { Five departments: } \\
3 \text { engineering, } 1 \text { administration, } 1 \text { project } \\
\text { management. Each of the departments } \\
\text { employed } 40-70 \text { engineers and technicians } \\
\text { who provided the company with the } \\
\text { necessary engineering competence within } \\
\text { a single technical field. In addition, they had } \\
\text { a Project Management Department ( } 20 \\
\text { project managers) responsible for the } \\
\text { execution and management of all the } \\
\text { contracted projects at the division. }\end{array}$ & $\begin{array}{l}\text { Six departments: } \\
\text { product management, technical } \\
\text { development, business development, IT } \\
\text { systems, juridical issues, project } \\
\text { management. Each functional department } \\
\text { employed } 2-15 \text { employees. In addition, they } \\
\text { had a project management department ( } 7 \\
\text { project managers) responsible for ensuring } \\
\text { that the development of new products and } \\
\text { services in the company was effective. }\end{array}$ \\
\hline Project scope & $\begin{array}{l}\text { Execution of complex contracts on turnkey } \\
\text { basis for international clients. }\end{array}$ & $\begin{array}{l}\text { Business and product development of new } \\
\text { telecom services and further development } \\
\text { of existing products. }\end{array}$ \\
\hline Project management structure & $\begin{array}{l}\text { Matrix structure: } \\
\text { All projects cross-functionally coordinated } \\
\text { by project managers at the project } \\
\text { management department. }\end{array}$ & $\begin{array}{l}\text { Matrix structure: } \\
\text { Projects cross-functionally coordinated by } \\
\text { project managers at different positions in } \\
\text { the organisation. }\end{array}$ \\
\hline \multicolumn{3}{|l|}{ Project portfolio } \\
\hline Number of projects & Approx. 30 & Approx. 60 (20 had official priority ${ }^{2}$ ) \\
\hline Size & $\begin{array}{l}\text { Budget: USD } 0.12-2.5 \text { million } \\
\text { Duration: } 1-5 \text { years }\end{array}$ & $\begin{array}{l}\text { Budget: USD } 0-6 \text { million } \\
\text { Duration: } 0.5-2 \text { years }\end{array}$ \\
\hline Technical complexity & High & Low \\
\hline Uncertainty in the projects & Primarily technical uncertainties & Primarily market uncertainties \\
\hline Characteristics of the portfolio & $\begin{array}{l}\text { Divergent, since the different projects were } \\
\text { constituted by client contracts comprising } \\
\text { tailored systems, although based on a } \\
\text { small number of generic technical } \\
\text { platforms. }\end{array}$ & $\begin{array}{l}\text { Scattered, comprising projects of many } \\
\text { different types and origins but with a } \\
\text { common outlet: the company's telecom } \\
\text { network. }\end{array}$ \\
\hline Prime emphasis for management & Product performance, effectiveness & Time, creativity \\
\hline
\end{tabular}

Both case-study companies responded to different environmental changes (for instance, increased competition, brand new products, service and process innovations, and an increased focus on time-to-market) by separating these custom assignments into various projects. This resulted in an increased usage of projects as a means of organising, which in turn meant that both companies established a portfolio of projects at an appropriate division. The signal and safety system company also initiated a change in their organisational structure to a project-based matrix organisation, with a dominant line organisation, when they acknowledged the need to manage the design and delivery of an increased number of complex product systems more efficiently. Meanwhile, the telecommunication company changed their organisational structure into a project-based organisation by initiating a project portfolio at their R\&D division, since they wanted to accentuate the importance of an innovative and creative product development internally. Both companies therefore initiated a transformation into a project-based organisation by announcing an increased use of projects as a means of organising. Therefore, both companies revealed that they were performing several projects of different scopes, sizes and priorities in parallel at the same time, all of them largely dependent on the same resources (personnel). Because of the increased number of projects, a departmental manager described one of the challenges - namely getting an overview of the project portfolio-like this:

"We managed to discuss the 4-5 most important projects with presentations by the 
project management one by one. Then we went through the issues at the technical and production divisions. So there was rarely time for holistic decisions, and we did not have the complete picture." (Head of Contract Division)

At both the organisations, all engineers in the functional departments were engaged in several cross-functional projects simultaneously. As a result, most project managers in the project management department had to accept the fact that the project team members were dividing their time between different project assignments. And since competencies were in short supply, most departmental managers had personnel involved in almost every on-going project at the division. Consequently, each functional department within the matrix organisation was the scene of an on-going political competition between the different project managers regarding priorities, resources, competencies, and attention:

"To run around every time there is a problematic situation and straighten things out, having to talk to ten different people, and get ten different answers is very frustrating... Maybe, we should arrange a training camp in internal procedures." (Project manager, Contract Division)

"Today, the most common reason for conflicts is the instant lack of competent personnel. Why did that project get so many better project members than me? Furthermore, they [Project managers, author's note] sometimes want to know why their project isn't prioritized when another project is." (Technical departmental manager, Contract Division)

At the Contract Division, all projects had a responsible project manager from the project management department and technical specialists (project team members) from the different technical departments. The project managers had formal responsibility for initiating, coordinating and controlling project work within the scope of their project. Usually, everybody on the project team (the project manager included) was engaged in several projects at the same time. The accepted approach when executing division business was therefore to include as little technical innovation as possible in the projects in order to make them costefficient. Likewise, at the R\&D Division, all projects also had a responsible project manager from the project management department and technical specialists (project team members) from the different technical departments. This meant that the main focus for the project management department was to manage the development work that was undertaken at the other departments in the division. Usually, everybody on the project team (the project manager included) was engaged in several projects at the same time. The accepted approach here when executing division business was to be as innovative as possible in the projects in order to attract new subscribers to the company's products and services. Therefore, both companies established a Project Management Office (PMO), in order to introduce project and portfolio management tools and techniques. Both organisations instructed the PMO to improve the project management process, first by developing standardised procedures for managing projects, and then by focusing on improving project portfolio management (for example, through resource allocation and prioritisation processes).

However, the project management procedures at the R\&D Division were rather immature and unsophisticated, and they established their PMO by grouping the most experienced project managers in the company together in one project management department. The department's role was to oversee the division's $\mathrm{R} \& \mathrm{D}$ projects, and to provide excellent project management services for the entire company. Prior to the creation of the PMO, the project managers were scattered all over the company and once the project management department was initiated they were all located there. This enabled both increased oversight and a stronger emphasis on professional project management of the $R \& D$ projects:

"Before we had a PMO, it wasn't clear what the project portfolio looked like, and none of us project managers really knew how to use the project management routines that existed. Everybody did things in their own way..." (Project manager, R\&D Division)

At the same time, a PMO manager with extensive experience was recruited from a competitor and he described his primary mission as to create a focus for and arouse interest in the coordination of the R\&D activities, enhance resource allocation and facilitate a more 
effective and innovative execution of the entire R\&D operation.

At the Contract Division, on the other hand, a mature and comprehensive process for project management that had been developed during the last decade was already in place, so the PMO emerged as a more organic structure when the need for resource allocation and prioritisation increased because the number of projects in the portfolio increased significantly. However, it was initially established in the same manner as the R\&D Division, by locating the most experienced project managers in the same department and then hiring a PMO manager.

When the two cases were analysed, three different dependencies between the projects emerged: a resource dependency, a two-fold technological dependency, and an organisational dependency. The resource dependency occurred when multiple projects simultaneously required the same resource. The technological dependency arose when projects were initiated with the same technical solution as a previous project (a "recycled" technical solution), or when one project's technical solution was dependent upon the completion of another project (such as a delivery project that needed to draw on the result of an R\&D project). The Head of the Contract Division emphasised the consequences when the technological dependency is not managed in this way:

"One has to make sure that a newly developed product actually fits into the existing system. Unfortunately, we have seen, time and again, that some project manager misses this, since it might delay the project's time-plan. To adapt a development project to the rest of the system takes time, and it's also something that's very difficult to make the salespeople acknowledge also." (Head of Contract Division)

In addition, there was a substantial need for organisational collaboration, which arose when different project activities had to be conducted with the knowledge, information, and/or expertise of several other parts of the line organisation. For instance, the Head of the R\&D Division emphasised that the following:

"Our department can only develop new products to a certain point, but then we have to make a handoff from development to operations, meaning production, billing, purchase, sales, customer service, and so on. And engaging them in the R\&D business is really hard, for the co-workers there are of course busy with the present, so how do we make them also take part in developing new products?" (Head of the $R \& D$ Division)

The main challenge was that all the dependencies produced negative effects in unexpected areas of the project portfolio. The Head of the Contract Division described it like this:

"We have 20-30 ongoing projects at the same time, then one project is delayed, and all our planning is disturbed. And it doesn't affect only this single project; instead everything slips away and ends up on top of each other." (Department manager, Contract Division)

Despite the initiation of a project management office and the establishment of a project portfolio management structure, the lack of information and communication was a constantly recurring theme in the interviews, meetings and observations at both companies where case studies were conducted. Steering groups and project sponsors often complained about inadequate or even incorrect information as the reason for decisions regarding, for example, the priority list of the projects.

"We still don't have a good overview of how many R\&D projects we have, or how many programs, or an obvious way to resource allocate." (Project manager, R\&D Division)

At the same time, the project managers and project team members often felt that they were being subjected to unreasonable demands to provide written information in the form of reports.

"I constantly write reports that I send to them 'up there'. But I don't really know what they do with them." (Project manager, $R \& D$ Division)

So, in both organisations, project portfolio management was concentrated on implementing and enhancing the necessary project and portfolio management processes as well as managing short-term issues concerning the prioritisation of projects and the distribution of personnel from low-prioritised, or smoothrunning projects to high-priority projects or projects in crisis.

"We do have the will to execute all of these new ideas. But what is lacking are the 
resources and an outspoken strategy of what we should focus on." (Project manager, $R \& D$ Division)

"We have an 80-20 relationship today. We can only do $20 \%$ of all the things we want to do. $80 \%$ we aren't able to handle, so you really have to prioritize." (Department manager $R \& D$ Division)

But, most of the time, the challenge was to manage the lack of available resources, as two project managers pointed out:

"It never goes exactly as planned. Some things will take longer, and other things come in between. People here don't work only with my project; they have other things to do also. So then something takes longer to do they're supposed to, don't go as fast as planned. Then you don't reach the project goal because of the resource situation we've got'. (Project manager, Contract Division)

"We have the desire to do something but often there is a lack of time and resources if we should go for something. So when we go to the other departments, they tell us they don't have the resources to do this." (Project manager, $R \& D$ Division

Consequently, after both organisations had established a PMO, it became possible for them to manage the majority of the short-term and ad hoc problems in their project portfolios. At the same time, the PMO was also supposed to focus on long-term knowledge development and process improvements. However, this was often subordinated to short-term problem solving on individual projects. Managing the problems, challenges and uncertainties was the responsibility of the PMO manager and the procedure followed at both companies was communication and acting as a link between all the important actors. At the Contract Division, the PMO manager's actions focused on improving communication between the line organisation and the project organisation, and coordinating the decision making of the steering committees, the CEO, the departmental managers and the project managers. At the R\&D Division, the PMO manager focused on communication and information flow between the R\&D Division and the departmental managers at other divisions, and on coordinating the integration of the R\&D activities with sales, billing, delivery, etc. For example, both organisations enhanced short-term decision making by forming an operative steering group that was responsible for evaluating, prioritising and distributing resources to every project in the portfolio, primarily on the basis of both urgent problems and resource, time and cost changes. The operative steering group (OSG) consisted of the division manager and all the departmental managers in the division; this group was in charge of all projects that required resources of any kind from the division. The steering group prioritises the resources for the project business of the entire division.

"If, for example, three kinds of resources are needed from operations, OSG can decide in favor of it and we are then entitled to make requests of operations that they have to put it in their next budget. Another example is that if a project manager needs a decision on more money for the project, OSG also decides on this." (Project manager, R\&D Division)

One prominent role that the PMO managers had to play was the role of mediator, negotiating to balance the interests of different projects. Since there was a constant lack of resources, this balancing act became important each time a project encountered problems, since problems spread quickly from one project to another. Further, the time-based process in the different projects was frequently interrupted by unexpected events that created distortions and jerkiness within the project portfolio as a whole. The result was continual negation between the portfolio managers and the project managers, departmental managers and PMO managers, focusing on matters like ways of increasing the information available for decision making on both human and technical issues (for a more detailed discussion of this, see Jerbrant \& Gustavsson, 2013). And this meant that in practice the PMO managers' working days were filled with different kinds of informal communicative actions such as phone calls, e-mails, personal and informal one-toone conversations, and formal one-to-many presentations. It could be argued that by functioning in this way the PMO managers took on an operative and informal stakeholder management role.

"Everybody works with a lot of projects at the same time, so one has to do the best one 
can. I usually walk around in the building with the purpose of talking to people, instead of just sitting in my office. Because all of the project members are either located on different floors of this building, or even in another city." (PMO manager, Contract Division)

Thus, we can conclude that, in both organisations, the PMO managers played a critical role in determining the quality of the knowledge and information that reached the different decision-making forums. The PMO managers also had overall responsibility for establishing a stronger interaction between the multi-project businesses and the companies' overall business strategies.

5

\section{Discussion}

In many project-based organisations, projects are seen as an effective and legitimate solution to the management of rapidly changing contextual factors (Christensen \& Kreiner, 1997). And when the organisational structures of the two companies at which case studies were performed are viewed in a historical perspective, it becomes clear that they both, in different ways, managed their contextual uncertainty by increasing the use of projects. But when cross-functional projects became increasingly common in the organisations, this created different coordination problems. The way in which both companies were using projects as a temporary organisational measure (Lundin \& Söderholm, 1995) implies that they were managing a complex social interaction, which means that the focus of project management was mainly on the integration of project activities conducted in different organisational units (Hobday, 2000). In both organisations, there was no main business except for the projects; no "functional work" existed. The coworkers performed all their engineering work within different projects. They were engaged in several projects at the same time, and they moved between successive projects over time, but all the time they belonged to the same functional department. Consequently, the projects interacted with each other extensively, using the same personnel and technology, and therefore the products of one project would become the prerequisites of another. Further, there was an on-going reorganisation, with people moving between different projects and work constellations.

The literature review illustrates how the management of PBOs often entails structuring efforts in the form of methods and tools for the planning, prioritisation, and control of the project portfolio (Cooper et al., 2002; Dawidson, 2006; Moore, 2010). But describing and analysing the daily execution of the two organisations' project-based activities also illustrates their uncertainty management, as Ward and Chapman (2003) say. This uncertainty management in a multi-project setting focuses on managing the unexpected events that occurred because of a resource allocation syndrome (Engwall \& Jerbrant, 2003), lack of communication, overloaded project managers, and organisational fragmentation.

Based on this, figure 1 illustrates the transition between the first level of uncertainty management and structuring in a traditional matrix organisation and the second level, which reflects uncertainty management in a multi-project setting.

According to Geraldi (2008), many management and organisational models state that an organisation is successful if it manages to combine organisational creativity and innovation with mechanical efficiency. However, most PBOs find it difficult to achieve this (Geraldi, 2008). The desire to avoid inefficiency and the urge to minimise uncertainty and risks increases the degree of control and bureaucratisation, which often means a decrease in creativity and flexibility. In both the organisations studied, there was a clear pattern reflecting a growing focus on structure, controlled hierarchy and bureaucracy caused by management's need for control, predictability and ability to allocate available resources and prioritise among all the simultaneous projects. There was also a blend of the typically hierarchical levels of the line organisations and the hierarchical levels needed to manage the multi-project business. There is therefore an increased need to designate a function that is in charge of and responsible for the control and execution of the entire project portfolio, while at the same time making sure that the project portfolio matches the company's business model and business goals (Pellegrinelli \& Garagna, 2009; Aubry et al., 2007, 2008). 


\section{Figure 1}

The transition between the first and second levels of the maturation model

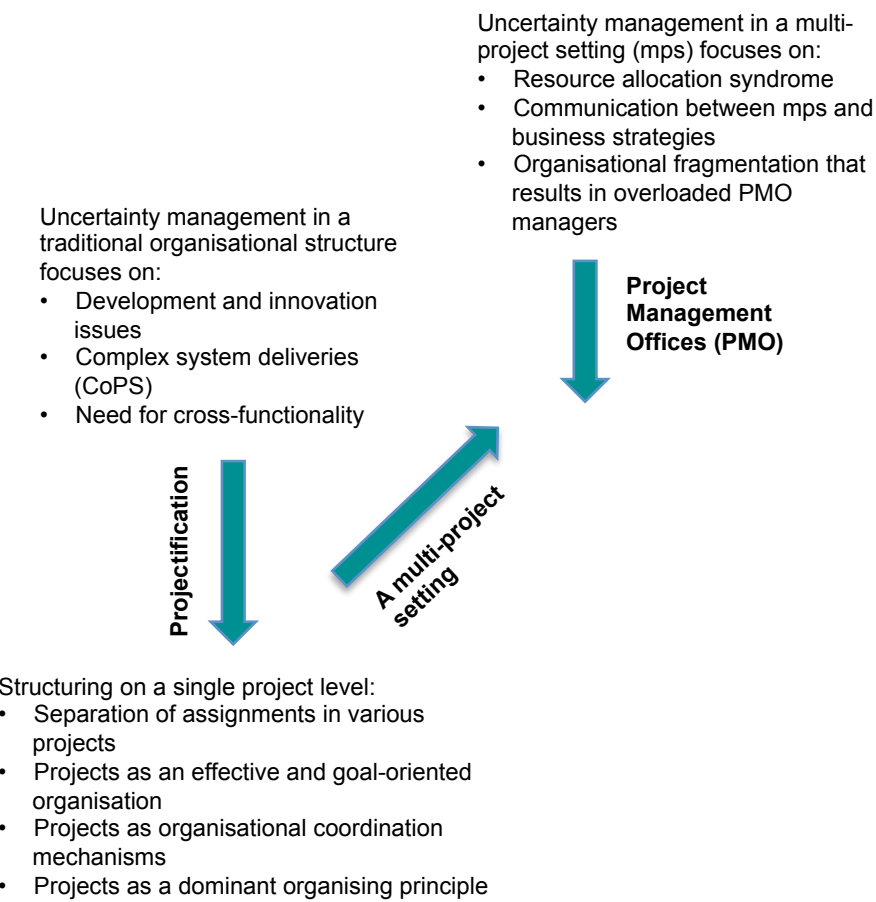

The substantial uncertainty experienced in managing the entire multi-project undertaking has boosted attempts to establish this function in project management offices (PMOs), for example. These are often seen, both in theory and in practice, as a means of both structuring a project-based business and also identifying where the responsibility for it lies (Aubry et al., 2007; Hobbs, Aubry \& Thuillier, 2008; Hobbs \& Aubry, 2010). Simultaneously, a PMO manager is usually responsible for organising the project management department as well as the project portfolio. This kind of PMO manager is also responsible for performing many of the management activities that provide the necessary organisational collaboration in a project-based business. On an aggregate level, the two casestudy companies reveal an almost identical pattern of problems and difficulties, as well as problem-solving strategies. In many ways, the management teams of the two divisions faced the same challenges as the companies' project portfolio managements. Both PMOs were good examples of how the purpose, design and operation of a PMO can adapt to the changing context (see Aubry et al., 2008). This study also emphasises how both organisations' PMOs can be regarded as unstable organisational structures, and how this instability can be seen as an ongoing restructuring process (see Hobbs et al., 2008). When studying these PMO managers, it became clear that they made a practice of doing walkabouts, which provided information and knowledge sharing, both top-down and bottom-up, thereby turning the PMO managers into information hubs. During these walkabouts, the PMO managers acquired up-to-date information on processes and progress as well as much-needed information on motivation and team spirit in order to obtain the overview they needed to prepare them to prioritise (Jerbrant \& Gustavsson, 2013). Both PMO managers also accepted responsibility for facilitating the execution of the entire project-based part of the organisation, by communicating in turn with the project managers, the technical departmental managers, all the other division managers, top management, and all internal and external clients and customers. This created a situation where the project management office became more of a social venue than a control unit (Pellegrinelli \& Garagna, 2009; Jerbrant, 2009). 
Based on this, figure 2 shows the transition at the second level of maturity in project-based organisations; this figure discusses the transition between uncertainty management and structuring in a multi-project setting.

\section{Figure 2}

The transition at the second level between uncertainty management and structuring in a multi-project setting

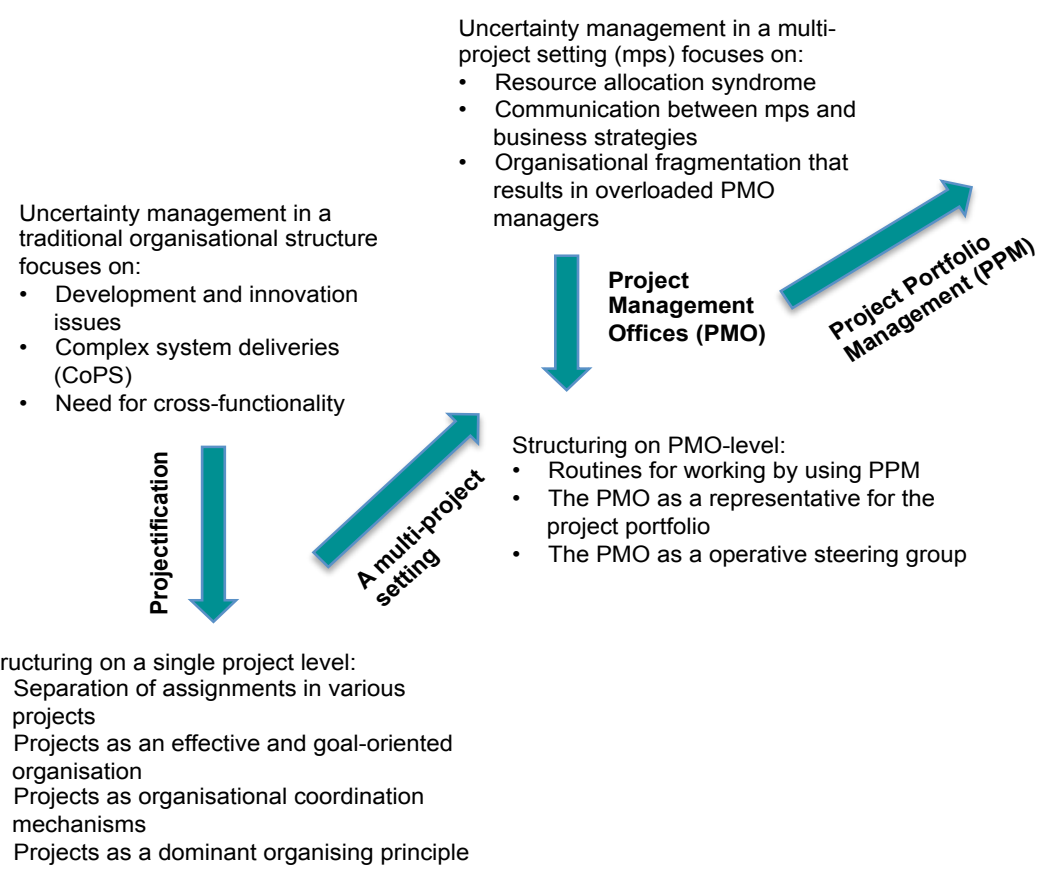

The increased use of projects that cut across established organisational boundaries forces project managers to deal with organised collective effort, integration and social interaction between many activities that are scattered throughout the line organisation. This means that numerous temporary organising processes in PBOs are permitted to emerge. One important management challenge for a project-based organisation that we perceive is the fact that all the projects depend on each other, in different ways. Resource dependency is often the most visible difficulty and, therefore, it receives the most attention from management. Resource dependency is one reason for the typical focus on the introduction of project portfolio management processes and practices, since these mainly provide support for the focus on project selection, resource allocation and prioritisation. In addition, introducing programme management usually solves the technological dependencies that occur either partly or entirely when different projects

are initiated using recycled technical solutions. However, the need for organisational collaboration that arises when different project activities are conducted with the knowledge, information, and/or expertise of several other parts of the line organisation is almost never managed by PPM processes. A key insight from this research is that many project-based organisations find it difficult to deal with the consequences and effects of organisational collaboration requirements because of the increasing number of projects that are performed as temporary organisations (see Packendorff (1995) meaning of the concept). The managers in charge of a project-based organisation have to acknowledge that the projects are interdependent on each other, rather than detached from each other (Jerbrant, 2009). It is therefore very important that the management of a multi-project setting emphasises all interdependencies, instead of merely focusing on the resource dependency.

This leads us to figure 3, which illustrates 
the transition between the second level of uncertainty management and structuring in a multi-project setting and the third level, where the uncertainty management in a project-based organisation is revealed.

\section{Figure 3}

The transition between the second and the third levels in the maturation model

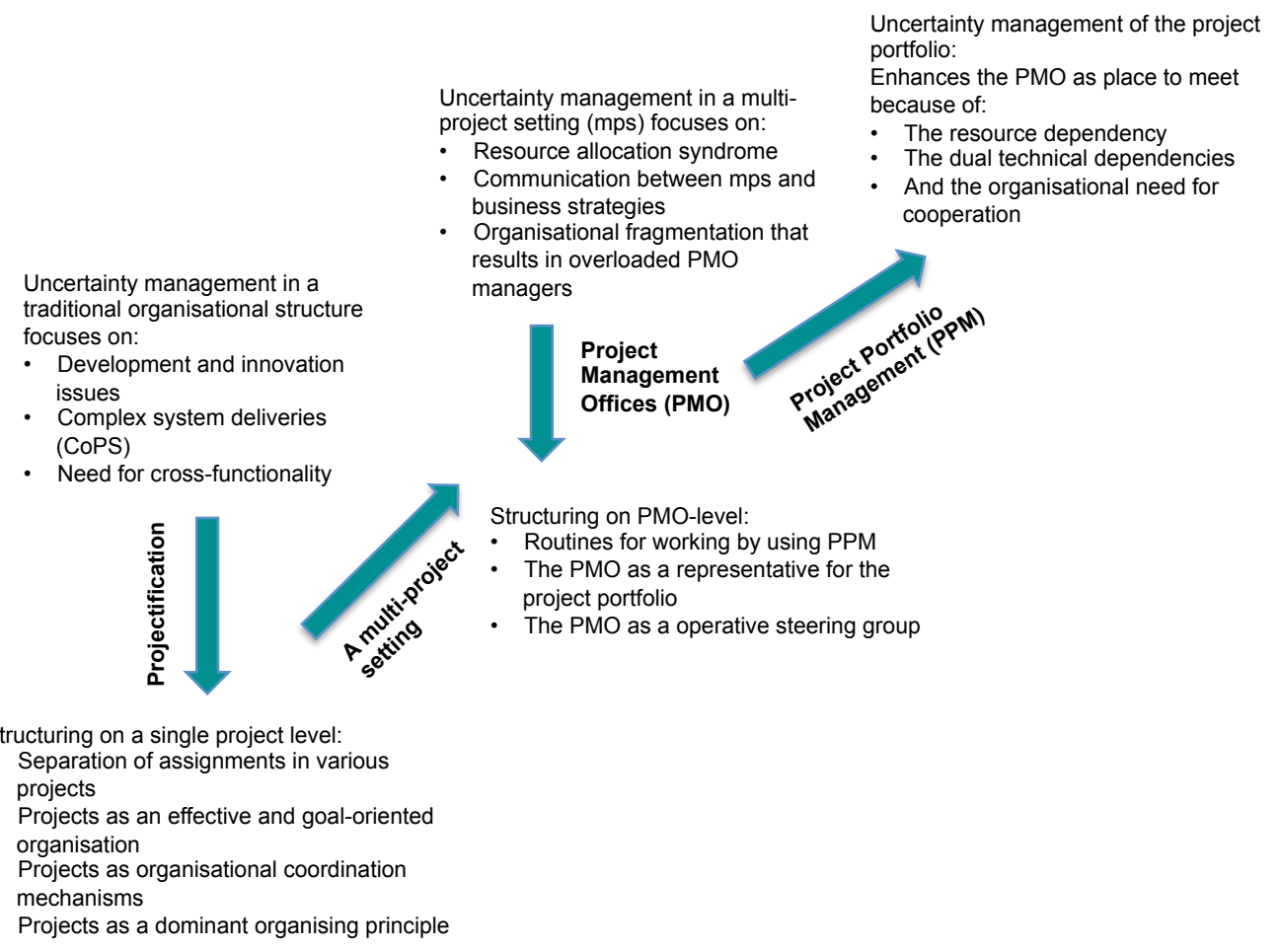

When using an organising perspective (Söderholm, 1991) to analyse a PBO, the analysis is based upon actors, actions, social interactions, situations, action processes, behaviour patterns and activities. In this way, not only structure and stability are revealed, but the continuity of the management process is maintained as well. These active, individual, and situationally grounded negotiations, often performed by the PMO manager, are designed to balance structural requirements with the need for situational leadership. Further, when the management of a project-based organisation is studied from the perspective of organisational theory, it becomes clear that communication, information, and decision-making are not adequate. For instance, it is not obvious how project managers should be given a say in the prioritisation process or how the communication between project managers and steering committees should work in order for both project managers and line managers to know how the different projects are being prioritised. To ensure that operations in a multi-project setting run as smoothly as possible, the PMO manager is also responsible for many negotiations with top management, departmental managers, project managers and project team members. Therefore, two of the processes that Petit (2012) and Petit and Hobbs (2010) emphasise, namely seizing and re-configuring, are mostly performed informally. These negotiations are also a way of establishing a correlation between the multi-project setting and the overall strategy of the company, something which has been identified as critical both in theory and in practice (Meskendahl, 2010; Moore, 2010). In the two organisations studied, the actions and negotiations performed by the coworkers at the project management 
department, especially those by the PMO manager, had to manage all of this.

The increased use of projects as way to organise the business gives rise to both certain events and the need for assumptions regarding the business strategy (Thiry \& Deguire, 2007). Therefore, the management and control of the project-based part of the business cannot be regarded as a separate issue, but should rather be seen as an integral part of executive management. Interaction between the PPM and the company's long-term strategies and business directions is essential (Moore, 2010; Turner, 2009).

An organisational perspective on the management of an industrial organisation and the control of its project-based business is necessary in view of the importance of managing the need for organisational cooperation that arises from the dynamic context. In the process, several important aspects of managing and organising the special dynamics that characterise PBOs are highlighted. One thing that emerges clearly is that organising a project-based business demands a kind of uncertainty management. In this way, both structure and stability become apparent and the continuity of the management process is maintained as well. However, the more active, individual and situational negotiation processes are not sufficiently highlighted, and the need for uncertainty management is diminished.

These actions and activities aim to achieve a balance between the need for structure and the need for situated management. Another aspect is the importance of integrating the management and organisation of the multi-project undertaking at a top-management level. This management of uncertainty, often performed by the PMO manager, is designed to balance structural requirements against the need for situational leadership on the third level of the maturation model.

\section{Figure 4}

A maturation model of PBO oscillating between structuring activities and uncertainty management

Uncertainty management in a traditional organisational structure focuses on:

- Development and innovation issues

- Complex system deliveries (CoPS)

- Need for cross-functionality
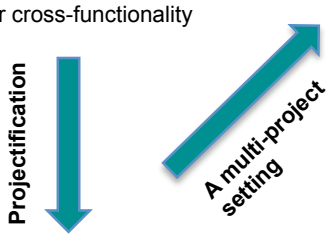

Structuring on a single project level:

- Separation of assignments in various

projects

- Projects as an effective and goal-oriented organisation

Projects as organisational coordination

mechanisms

- Projects as a dominant organising principle
Uncertainty management of the project portfolio:

Enhances the PMO as place to meet because of:

- The resource dependency

- The dual technical dependencies

project setting (mps) focuses on:

- Resource allocation syndrome

- And the organisational need for

business strategies

cooperation

Organisational fragmentation that

results in overloaded PMO

managers

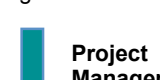

Mroject Offices (PMO)
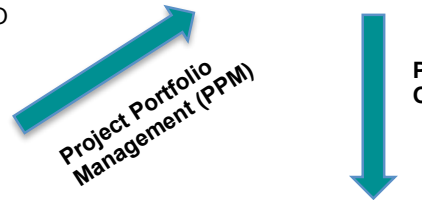

Project-based Organisations

Structuring on PMO-level:

- Routines for working by using PPM

- The PMO as a representative for the project portfolio

- The PMO as a operative steering group

Structuring on an organisational level:

- Business program level in the portfolio

- Optimal design of the projectbased organisational structures

- Multi-project management as top management responsibility

- Project portfolio as a strategic spearhead

- Project adapted strategic HRM But:

- Uncertainty management, situational leadership, as always remaining multi-project management responsibility 
6

\section{Conclusions}

The purpose of this paper was to present a descriptive model that elucidates the maturation processes in a project-based organisation, as well as to provide an enhanced understanding of multi-project management in practice. The maturation model that has been developed provides an understanding of how the management of project-based companies evolves, because of their need to be agile and adaptable in a changing environment. This causes the focus for their project-, program- and portfolio management to transfer between structuring administration and managing any uncertainty, which enables their multi-project management maturity to increase.

We can therefore conclude that the maturation model describes an organising process that oscillates between structuring activities and uncertainty management, thus providing a dialectical understanding of how solutions on one level can cause problems on new levels. This maturation model resembles a staircase where each step involves a better understanding of the management, governance and organising of a project-based organisation. This illustrates how, by increasing the number of projects, uncertainty management in a traditional organisational structure often takes care of both rapidly changing contextual environmental requirements and the business operational needs of cross-functionality. But once the projects become a dominant organising principle, resource allocation problems arise, as well as an increased need for communication to overcome the problems of organisational fragmentation, overburdened project managers, and multiproject professionals. This, in turn, places the emphasis on how to structure the project management office level, which implies an increased awareness of routinised project portfolio management, operational steering groups, and the project office as representative of the project portfolio. However, since dependencies and links between the many parallel projects exist, there is a greater need for uncertainty management in the execution of project-based activities. Lastly, structuring on an organisational level means enhancing the strategic connection for PBOs, thus making multi-project management a top management responsibility, aligning it with the strategy, adapting it to the organisation's human resource management, as well as emphasising uncertainty management, situational leadership, and the ever-present multi-project management responsibility.

The main result presented in this paper is therefore both a maturation model of PBO that illustrates how multi-project management evolves between structuring administration and managing uncertainty, and an emphasis on the importance of uncertainty management in project portfolio management through positive individual actions and situated management actions that have to be undertaken in order to coordinate, synchronise and communicate the required knowledge and skills.

Based on this, we can conclude that it is essential to understand the balance between structuring mechanisms and the ability to handle the ever-present uncertainty in PBOs. This balance is necessary in order to manage the volume of changing requirements-both operational and contextual-during a certain period of time, thereby making it possible to enhance the organisation's dynamic capability.

\section{7}

\section{Theoretical and practical implications}

Studying PBOs from both a process and a practice perspective clarifies the way the management and control of PBOs has to manage two types of organisational coordination requirements. The first is the need for coordination in the part of the business that is project-based, where a need to integrate several different functional areas exists. The second is the need for coordination that arises because the project portfolio has to be aligned with the overall business strategy. Both of these aspects require further exploration, and another appropriate area for research is therefore the strategic link between the project portfolios and the overall business strategy as well as the visualisation of business development from the levels of both structuring and uncertainty management. Furthermore, there is a need for more research on the maturation model (in order to facilitate its continuous development), as well as continued studies on the content of uncertainty 
management in different types of project-based organisations.

Regarding the implications for practice, this thesis emphasises the fact that formal portfolio management methods need to be supplemented by situated actions to deal with the specific kinds of mechanisms characteristic of projectbased organisations. This means, for example, developing an understanding of the PMO manager's active and situation-specific documents, patterns of behaviour, and guiding principles.

Endnotes

1 Specific characteristics of a process ontology according to Sergi (2012:349).

2 The remainder of the project portfolio focused on development ideas: the company's log of the direction in which the company is heading regarding its development of new products and services.

\section{References}

ARVIDSSON, N. 2009. Exploring tensions in projectified matrix organisations. Scandinavian Journal of Management, 25:97-107.

AUBRY, M., HOBBS, B. \& THUILLIER, D. 2007. A new framework for understanding organisational project management through the PMO. International Journal of Project Management, 25:328-336. AUBRY, M., HOBBS, B. \& THUILLIER, D. 2008. Organisational project management: A historical approach to the study of PMOs. International Journal of Project Management, 26:38-43.

BERGER, L.P. \& LUCKMAN, T. 1998. Knowledge Sociology-How individuals perceive and shape their social reality. Stockholm: Wahlström \& Widstrand. (In Swedish: Kunskapssociologi - hur individen uppfattar och formar sin sociala verklighet. Andra upplagan. Stockholm: Wahlström \& Widstrand.) BLICHFELDT, B. \& ESKEROD, P. 2008. Project portfolio management-There's more to it than what management enacts. International Journal of Project Management, 26:357-365.

BLOMQUIST, T. \& SÖDERHOLM, A. 2002. Projectified society-How project management got carried away. In Sahlin \& Söderholm (eds.) 2002. Beyond project management: New perspectives on the temporarypermanent dilemma. Stockholm: Liber Ekonomi.

BLOMQUIST, T. \& MÜLLER, R. 2006. Practice, roles and responsibilities of middle managers in program and portfolio management. Project Management Journal, 37(1):52-66.

BLOMQUIST, T., HÄLLGREN, M., NILSSON, A. \& SÖDERHOLM, A. 2009. Projects-as-Practice: Making project research matter. Project Management Research, 41(1):5-16.

CHRISTENSEN, S. \& KREINER, K. 1997. Projektledning - att leda och lära i en ofullkomlig värld. Köpenhamn: Academia Adacta. (In English: Project Management - to manage and learn in an imperfect world. Copenhagen: Academia Adacta.).

COOPER, G.R., EDGETT, S. \& KLEINSCHMIDT, J.E. 2002. Optimizing the stage-gate process: What bestpractice companies do, part I. Research Technology Management, 45(5):21-27.

CRAWFORD, L., POLLACK, J., ENGLAND, D. 2006. Uncovering the trends in project management: Journal emphases over the last 10 years. International Journal of Project Management, (24):175-184

DAINTY, A., MOORE, D. \& MURRAY, M. 2006. Communication in Construction. Theory and Practice. London: Taylor \& Francis.

DANILOVIC, M. \& SANDKULL, B. 2005. The use of dependence structure matrix and domain mapping matrix in managing uncertainty in multiple project situations. International Journal of Innovation Management, (23):193-203.

DAWIDSON, O. 2006. Project portfolio management-An organising perspective. $\mathrm{PhD}$ thesis, Chalmers University of Technology, Gothenburg.

DE MAIO, A., VERGANTI, R. \& CORSO, M. 1994. A multi-project management framework for new product development. European Journal of Operational Research, 78(2):178-191.

DE REYCK, B., GRUSHKA-COCKAYNE, Y., LOCKETT, M., CALDEMI, S.R., MOURA, M. \& SLOPER, A. 2005. The impact of project portfolio management on information technology projects. International Journal of Project Management, 23:524-537. 
DVIR, D., RAZ, T. \& SHENHAR, A. 2002. An empirical analysis of the relationship between project planning and project success. International Journal of Project Management, 21:89-95

ELONEN, S. \& ARTTO, A.K. 2003. Problems in managing internal development projects in multi-project environments. International Journal of Project Management, 21:395-402.

ENGWALL, M. \& JERBRANT, A. 2003. The resource allocation syndrome. International Journal of Project Management, 21:403-409.

ENGWALL, M. 2003. No project is an island: Linking projects to history and context. Research Policy, 32:789-808.

ESKEROD, P. 1996. Meaning and action in a multi-project environment: Understanding a multi-project environment by means of metaphors and basic assumptions. International Journal of Project Management, 14(2):61-65.

GANN, D. \& SALTER, A. 1998. Learning and innovation management in project-based, service- enhanced firms. International Journal of Innovation Management, 2(4):431-454.

GERALDI, J. 2008. The balance between order and chaos in multi-project firms: A conceptual model. International Journal of Project Management, 26:348-356.

GERALDI, J., LEE-KELLEY, L. \& KUTSCH, E. 2010. The Titanic sunk, so what? Project manager response to unexpected events. International Journal of Project Management, 28:547-558.

GLASER, B.G. \& STRAUSS, A.L. 1967. Discovery of grounded theory: Strategies for qualitative research. Berlin: Walter de Gruyter.

GUNNARSSON, S., LINDE, A. \& LOID, D. 2000. Is s standardization applicable to project managers of multi-project companies? In: Paradoxes of project collaboration in the global economy: Interdependence, complexity and ambiguity. IRNOP IV. Sydney: University of Technology:136-146.

HENDRIKS, M.H.A., VOETEN, B. \& KROEP, L. 1999. Human resource allocation in a multi-project R\&D environment. International Journal of Project Management, 17(3):181-188.

HOBBS, B., AUBRY, M. \& THUILLIER, D. 2008. The project management office as an organisational innovation. International Journal of Project Management, 26:547-555.

HOBBS, B. \& AUBRY, M. 2010. The project management office (PMO)—A quest for understanding. Final research report. Newtown Square, Pennsylvania. Project Management Institute.

HOBDAY, M. 2000. The project-based organisation: An ideal form for managing complex products and systems? Research Policy, 29:871-893.

JERBRANT, A. \& KARRBOM GUSTAVSSON, T. 2013. Managing project portfolios: Balancing flexibility and structure by improvising. International Journal of Managing Projects in Business, 6(1):152-172.

JERBRANT A. 2013. Organising project-based companies: Management, control and execution of projectbased industrial operations. International Journal of Managing Projects in Business, 6(2):365-378.

JERBRANT, A. 2009. Organisering av projektbaserade företag - Ledning, styrning och genomförande av projektbaserad industriell verksamhet. PhD thesis. Royal Institute of Technology, Sweden (In English: Organising project-based companies: Management, control, and execution of project-based industrial operations.)

JONAS, D., KOCK, A. \& GEMÜNDEN, H.G. 2010. The impact of portfolio management quality on project portfolio success. In: EURAM 2010. Rome.

LINDFORS JOHANSSON, M. 1993. Att utveckla kunskap - om metodologiska och andra vägval vid samhällsvetenskaplig kunskapsbildning (In English: Developing knowledge - on methodological and other choices in the social science knowledge.) Lund: Studentlitteratur.

LINDKVIST, L. 2004. Governing project-based firms: Promoting market-like processes within hierarchies. Journal of Management and Governance, 8(1):3-25.

LUNDIN, R. \& SÖDERHOLM, A. 1995. A theory of the temporary organization. Scandinavian Journal of Management, 11(4):437-455.

LYCETT, M., RASSAU, A. \& DANSON, J. 2004. Programme management: A critical review. International Journal of Project Management, 22:289-299.

MCDONOUGH, E.F. \& SPITAL, C.F. 2003. Managing project portfolios. Research Technology Management, May-June, 46(7):40-46. 
MESKENDAHL, S. 2010. The influence of business strategy on project portfolio management and its success-A conceptual framework. International Journal of Project Management, 28:807-817.

MIDLER, C. 1995. "Projectification" of the firm: The Renault case. Scandinavian Journal of Management, 11(4):363-375.

MOORE, S. 2010. Strategic portfolio management: Enabling a productive organisation. Hoboken: Wiley.

OLFORD, J.W. 2002. Why is multiple-project management hard and how can we make it easier? In: Pennypacker \& Dye (eds.) 2002. Managing multiple projects. New York: Marcel Dekker.

PACKENDORFF, J. 1995. Inquiring into the temporary organization: New directions for project management research. Scandinavian Journal of Management, 11(4):319-334.

PAYNE, H.J. 1995. Management of multiple simultaneous projects: A state-of-the-art review. International Journal of Project Management, 13(3):163-168.

PAYNE, H.J. \& TURNER, J.R. 1999. Company-wide project management: the planning and control of programmes of projects of different types. International Journal of Project Management, 17(1):55-59. PELlEGRINELli, S., PARTINGTON, D., HEMINGWAY, C., MOHDZAIN, Z., SHAH, M. 2007. The importance of context in programme management: An empirical review of programme practices. International Journal of Project Management, (25):41-55

PELLEGRINELLI, S. \& GARAGNA, L. 2009. Towards a conceptualisation of PMOs as agents and subjects of change and renewal. International Journal of Project Management, 27(7):649-656.

PENNYPACKER, S.J. \& DYE, D.L. 2002. Project portfolio management and managing multiple projects: Two sides of the same coin? In: Pennypacker \& Dye (eds.) 2002. Managing multiple projects. New York: Dekker.

PETIT, Y. 2012. Project portfolios in dynamic environments: organising for uncertainty. International Journal of Project Management, 30:539-553.

PETIT, Y. \& HOBBS, B. 2010. Project portfolios in dynamic environments: Sources of uncertainty and sensing mechanisms. Project Management Journal, 41(4):46-58.

PRENCIPE, A. \& TELL, F. 2001. Inter-project learning: Processes and outcomes of knowledge codification in project-based firms. Research Policy, 30(9):1373-1394.

SERGI, V. 2012. Bounded becoming: Insights from understanding projects in situation. International Journal of Managing Projects in Business, 5(3):345-363.

SÖDERHOLM, A. 1991. Logic of organizing: A study of local industrial policy. In Swedish: Organiseringens logik, en studie av kommunal näringslivspolitik. PhD Umeå University.

SÖDERLUND, J., 2004. On the broadening scope of the research on projects: A review and a model for analysis. International Journal of Project Management, 22:655-667.

SYDOW, J., LINDKVIST, L. \& DEFILLIPI, R. 2004. Project-based organizations, embeddedness, and repositories of knowledge. Organisation Studies, 25(9):1475-1489.

TELLER, J., UNDER, B.N., KOCK, A. \& GEMÜNDEN, H.G. 2012. Formalization of project portfolio management: The moderating role of project portfolio complexity. International Journal of Project Management, 30(5):596-607.

THIRY, M. \& DEGUIRE, M. 2007. Recent development in project-based organizations. International Journal of Project Management, 25:659-658.

TURNER, J.R. 2009. The handbook of project-based management ( $3^{\text {rd }}$ ed.) New York: McGraw-Hill. UNGER, B.H, KOCK, A., GEMÜNDEN, H.G \& AUBRY, M. 2012. The three roles of a project portfolio management office: Their impact on portfolio management execution and success. International Journal of Project Management, 30(5):608-620.

VAN DER MERWES, P.A. 1997. Multi-project management organizational structure and control. International Journal of Project Management, 15(4):223-233.

WARD, S. \& CHAPMAN, C. 2003. Transforming project risk management into project uncertainty management. International Journal of Project Management, 21:97-105.

WINCH, G.M. 2010. Managing construction projects. Wiley-Blackwell. 